\title{
Length of Chain in Pyramidal Firms towards Expropriation of Minority Interest
}

\author{
Irfah Najihah Basir Malan ${ }^{1}$, Norhana Salamudin ${ }^{2} \&$ Noryati Ahmad ${ }^{2}$ \\ ${ }^{1}$ Faculty of Business Management, Center of Postgraduate \& Professional Studies, Universiti Teknologi MARA, \\ Selangor, Malaysia \\ ${ }^{2}$ Arshad Ayub Graduate Business School, Universiti Teknologi MARA, Selangor, Malaysia \\ Correspondence: Irfah Najihah Basir Malan, Faculty of Business Management, Center of Postgraduate \& \\ Professional Studies, Universiti Teknologi MARA, Selangor 40450, Malaysia. Tel: 60-1-2690-9217. E-mail: \\ irfajiha@gmail.com
}

Received: February 12, 2015

Accepted: March 24, 2015

Online Published: March 25, 2015

doi:10.5539/ibr.v8n4p303

URL: http://dx.doi.org/10.5539/ibr.v8n4p303

\begin{abstract}
It is documented that there is a large divergence of cash flow rights and control rights in ownership concentrated corporations whereby power lies in the hands of the ultimate controlling shareholder especially for Malaysian pyramidal firms. The divergence of these two rights via length of chain leads to the expropriation of minority shareholders interest. Thus, this study aims to examine the factors influencing the length of chain of Malaysian pyramidal firms implying expropriation of minority interest. This study hypothesizes that the distance separating the ultimate controlling shareholder from their affiliated firms is positively related to the presence of eventual negative shocks and vice-versa. Applying the Attig Model and Panel Generalised Least Square (GLS) estimation on Malaysian pyramidal firms between 1990 to 2010 as the underlying statistical test, the results show that there is association between the length of chain separating ultimate controlling shareholder from the affiliated groups and the entrenchment effect. Factors influencing the length of chain such as risk, cash, size, TobinQ, duality, financial institution and liquidity posit significant results and consistent with the entrenchment effect. Future research needs to highlight on identifying the heterogeneous factors that improve the generalizability of research.
\end{abstract}

Keywords: cash flow rights, control rights, length of chain, expropriation, minority interest, pyramidal firms, Malaysia

\section{Introduction}

According to previous studies, pyramidal firms tend to have excess voting rights over cash flow rights (Claessens, Djankov, Fan, \& Lang, 2000; La Porta, Lopez, \& Shleifer, 1999). Pyramidal firms are prevalent in Malaysia due to the concentrated ownership of the largest ultimate controlling shareholders (Claessens et al., 1999; Claessens et al., 2000). The greater the dispersion of actual ownership and control, the longer is the length of chain separating the ultimate controlling owner from affiliate firms.

Excess voting power is associated with expropriation behavior (Claessens et al., 2000). According to Claessens et al. (1999), the problem which is associated to ownership concentration is the agency problem which occurs among ultimate controlling shareholders and minority shareholders. There is a high incidence of agency problems due to the divergence of cash flow rights and control rights via length of chain in the pyramidal firms. It is because the ultimate controlling shareholders at the peak of the pyramid takes advantage of the higher control rights to increase leverage which leads to opportunity of expropriation for minority shareholders at the bottom of the pyramids (Claessens et al., 2000).

Numerous studies have been undertaken on ownership structure in Malaysia. For instance, determinants of ownership structure (Chu \& Cheah, 2006), the nature of ownership structure, governance and firm value (Tam \& Tan, 2007) and relation of investment behavior and capital structure on ownership structure. Few studies have taken into account the factors that influence the length of chain in pyramidal firms towards expropriation of minority interests. Thus far, only Fauzias and Bany (2005) investigate the divergence of cash flow rights from control rights arising from pyramidal firm's capital structure. Their finding indicates that entrenchment effect occurs in distressed firms when the divergence between cash flow rights and control rights exist via such a 
structure.

This present study provides additional insight on the length of chain factors among Malaysian pyramidal firms. Although much has been written on the issues of pyramidal structure, empirical research in this area has been less forthcoming in developing countries particularly Malaysia. This study is very important and need to be explored as Malaysian pyramidal firms have high ownership concentration in the hands of ultimate controlling shareholders, where the risk of expropriation of minority shareholders is severe (Claessens et al., 1999). This study selects pyramidal firms as a sample in analyzing the factors that influence the length of chain towards expropriation of minority interest. Pyramidal firm is considered as unique concentrated business environment from other categories of ownership structure (Fauzias \& Zunaidah, 2007). It is because dilution and exacerbation of ultimate controlling owner misconduct are more pronounced resulting from the length of ownership chain in a pyramidal firm. This study focuses on a specific country study which is Malaysia to provide a better understanding in emerging countries. Even though analyzing a single country's firms could be regarded as a limitation for this study as the consequences may not be transferable to other institutional environments, but single-country studies facilitate the author to overcome a problem associated with multicountry studies. So, concentration on a country helps to control for different factors that influence studies across countries, therefore providing a deeper understanding of the issues being examined.

The motivation for this study comes from the findings of Attig, Fischer and Gadhoum (2003) and Claessens et al. (2000) who focus on the phenomenon of actual ownership and control in pyramidal firms and dilution of minority interests which brings a negative effect on Asian firms' value. Previous study by Claessens et al. (2000) on the other hand shows that the level of control which the Asian pyramidal firms have over the Asian economies is significant. For example, the East Asian pyramidal firms control $80 \%$ of the East Asian economies, as computed in terms of total corporate assets. For Malaysian case in particular, pyramidal firms control $28 \%$ of the value of listed corporate assets. Their studies also find that Malaysia has the third highest concentration of control after Thailand and Indonesia. So, this study tries to answer the issue of whether there is an indication of expropriation of minority interest among Malaysian pyramidal firms by analyzing the possible factors that influence the length of chain. In this sense, the longer the length of chain of a pyramidal firm, the higher the probability of expropriation of the firm especially at lower levels.

The rest of the study is organized in the following manner. The next section presents related previous studies and hypothesis testing development. The following section discusses methodology. Data analysis section provides discussion of the findings. Final section contains conclusion.

\section{Literature Review}

\subsection{Pyramidal Structure and Length of Chain}

A pyramidal structure is a group of firm affiliation to pyramid whose exhibits a top-down chain of control. According to Attig et al. (2003), a firm is regarded as pyramidal affiliated firms if it is controlled via a pyramidal structure and has at least one intermediary firm in its ownership chain. Basically, the ultimate controlling owners are placed at the peak of the pyramid with successive layers of firms below. A direct result of the pyramidal structure is a divergence of actual ownership, or cash flow rights, from voting power or control rights, specifically for firms placed in the bottom tier of the structure (Claessens, Djankov, \& Lang, 2000). Cash flow rights portray owner's actual ownership in a firm (Claessens et al., 2000b). Chapelle (2005) defines control is subject to the majority voting rule where the control ratio of a shareholder is gained by dividing the share of control he can exercise either directly or indirectly in a firm, by the percentage of shares he actually possesses in that firm. Logically, owners' control rights in a firm should be represented by the owner's cash flow rights that arise from his actual investment. But because of the pyramidal structure effect, these two rights may not be equal.

The divergence of these two rights in pyramidal structure contributes to agency problem among ultimate controlling shareholders and minority shareholders. According to Cronqvist and Nilsson (2003), since the ultimate controlling shareholders own substantially higher control rights than cash flow rights that they control in pyramidal firms, they tend to make decisions for their own private benefit. This phenomenon shows that non-aligned interest between both parties contributes to agency problem arising from concentrated ownership with cash flow rights and control rights diversion.

Almeida and Wolfenzon (2006) also agree that pyramidal structure is created to split cash flow rights from control rights because it has some degree of divergence between these two rights. Faccio and Lang (2002) examines Western European Corporations and reveals that pyramidal structure shows the dominant mechanism to enhance control. In the case of Malaysia, pyramids account for 39.3\% of total listed firms (Claessens et al., 
1999). This indicates that pyramidal structures are the most prevalent method to enhance control employed by most Malaysian corporations.

Due to prevalent pyramidal structure practice, a portion of large Malaysian firms are controlling more entities beyond their level of ownership in each firm (Khatri, Leruth, \& Piesse, 2002). It can be illustrated clearly as follows. For instance, the ultimate controlling owner owns $10 \%$ of the stock of a publicly traded firm A, which in turn has $30 \%$ of the stock of firm B. It is then said that the ultimate controlling owner controls $10 \%$ of firm B; the weakest link in the control chain (La Porta et al., 1999). In contrast, the ultimate controlling owner only owns about $3 \%$ of the cash flow rights of firm B, the product of the two ownership stakes along the chain. Thus, the control right posits higher than cash flow rights in the pyramidal structure.

In aspects of length of chain, the pyramidal structure can be in the form of two tiers, three tiers and it may go up to several number of tiers or layers. So, the longer the length of chain of a pyramidal structure, the probability of expropriation of the firm at the lower level is higher. In other words, the length of chain within the pyramidal structure contributes to form an impervious veil behind which ultimate controlling owners engage in expropriating behavior. According to Bunkanwanicha and Wiwattankantang (2008), firms are placed in different tiers in the pyramidal structure to provide a specific purpose. For example, those firms at the lower tiers in the pyramidal structure are used to undertake riskier investments that may generate large cash flow but those firms in the upper layers are used to absorb the positive outcomes from the successful investments undertaken by the affiliates.

Affiliates with large dividend payout, liquid stocks and high debt ratio would be placed in the layer near the ultimate controlling owner while those which are large in size, risk takers and generate excess cash flow is placed at the bottom tier of the pyramidal structure (Attig et al., 2003). So, to examine the factors that influence the length of chain separating the ultimate controlling owner from the affiliates, cash flow rights to control rights ratio is the proxy used for this study. The ultimate controlling owner' cash flow right to control right ratio is highly associated with the number of layers separating the ultimate controlling owner from his affiliated firms and these determinants will be examined to indicate whether they reflect the proposition. In this case, the ratio accounts for the spread between the ultimate control and ultimate ownership (Attig et al., 2003).

Most of the studies have been done on pyramidal structure in the viewpoint of divergence of ownership and control (Claessens et al., 2000a; La Porta et al., 1999, 2000a), correlation between firm performance and ownership structure (Baek, Kang, \& Park, 2004; Hughes, 2009; Lemmon \& Lins, 2003), tunnelling effect of pyramidal structure (Cheung, Rau, \& Stauraitis, 2006; Friedman, Johnson, \& Mitton, 2003; Riyanto \& Toolsema, 2008) and other aspects. However, this study empirically examines in the Malaysian context the factors that influence the length of chain in pyramidal firms towards expropriation of minority interest. Empirical test on this governance issue is still relatively limited especially in Malaysian corporate scene, thus an extensive analysis in this direction is warranted. The authors only focus on pyramidal structure because it is the most pronounced mechanism in the discrepancy of cash flow rights and control rights which stimulate weaker dilution of minority shareholders interest. This study differs from previous researches which uses a unique and extensively data set of pyramidal firms. The amount of data in this study enables estimating an actual scenario specifically in Malaysia. It is expected that the study will give some insights on the governance subjects in the developing countries such as Malaysia. So, the highlighted issue might abridge gap in comprehending the factors that influence the length of chain in pyramidal firms towards dilution of minority shareholders' interests.

\subsection{Excess Control Rights and Minority Shareholder Expropriation}

The wedge between the ultimate controlling shareholders's cash flow rights and control rights is known as excess control rights (Claessens et al., 2000). Meanwhile, expropriation of minority interest is subject to the power misuse by large ultimate controlling shareholders in order to obtain control and generate their own interests (empire building) at the expense of minority shareholders (Shleifer \& Vishny, 1997). In firms with actual ownership and control spread, pyramidal firms allow higher control rights over cash flow rights. Thus, the control right concentration enables the ultimate controlling shareholders to tunnel corporate resources for personal benefits with no regards to minority shareholders in lower level firms by appointing directors they preferred and making decisions on issuance of securities even though their ownership is smaller (Attig, 2007).

Numerous literatures have shown that control rights concentration exists in countries across the world. For instance, La Porta et al. (1999) study corporate ownership on 27 countries around the world. They report that large ultimate controlling shareholders often establish power over firms despite having minimal cash flow rights. Meanwhile, other studies by Bebchuk, Kraakman and Triantis (2000) state how shares of pyramidal ownership firms can be used to gain control of voting rights that are well in excess of cash flow rights. As a result of this 
divergence, ultimate controlling shareholders can use the control granted by high voting rights to engage in expropriating behavior towards minority shareholders; however, as the divergence magnitude increases, the ultimate controlling shareholders' cash flow rights turn to decrease. Thus, they able to enjoy all of the private benefits of control while internalizing only a small fraction of the costs. Bebchuk et al. (2000) also argue that high diversion level between cash flow rights and control rights increases the risk of minority shareholder expropriation because it gives the ultimate controlling shareholder both the power and the incentives to derive private benefits of control.

Empirical studies investigating the control rights excess in relation with minority shareholder expropriation are increasing in number. Studies on the emerging markets, mostly Asian countries, provide strong evidence with respect to the adverse implication of excess control rights on minority shareholder expropriation (Baek et al., 2004; Claessens et al., 2002; Joh, 2003; Lemmon \& Lins, 2003; Lins, 2003; Mitton, 2002). Based on Villalonga and Amit (2006) studies on a sample of Fortune 500 firms, they depict that ownership concentration is positively associated with higher profitability, whereas control-enhancing mechanisms such as pyramidal structure posits higher risk of minority shareholder expropriation and ultimately leads to firm devaluation. Meanwhile, Bozec and Laurin (2004) who researched the largest Canadian publicly-listed firms, demonstrate that excess control rights negatively influence firm performance as well as exacerbate the risk of expropriation of minority shareholders' interests when the ultimate controlling shareholder's share of the equity (cash flow rights) is small. The findings of Bozec and Laurin (2008) suggest that this negative relationship is even stronger whenever the firm creates high free cash flows. Other study by Attig et al. (2004) also reports the same findings. They also agree that the dilution of minority shareholders' interests as well as firm performance might be affected due to the firms with ultimate controlling shareholders own substantially more control rights.

So, it can be conjectured that when concentration of ownership exists, the length of chain as well as divergence of ownership and control becomes a vital issue. It is because the possibility for the risk of expropriation towards minority shareholders' interests is higher when the firms with ultimate controlling shareholders have excess control. Due to the concern of wedge between cash flow rights and control rights, most of the researchers have studied such relationship on various aspects such as legal (La Porta et al., 1999; 2000), methods of enhancing control (Faccio \& Lang, 2002) and corporate leverage (Du \& Dai, 2005; Fauzias \& Bany, 2005). However, there are relatively few studies on the length of chain in pyramidal firms especially in Malaysia. So, this study intends to examine the length of chain factors in pyramidal firms towards expropriation of minority interest. This study fills the gap in literature by investigating the length of chain data among Malaysian pyramidal firms. The results offer valuable evidence for the capital market in Malaysia. In addition, the research results generated from study conducted in other countries may not be the similar as the research results produced from analysis done locally. The sign and strength of the coefficients and the importance of the variable may vary due to the uniqueness of the Malaysian public listed firms' especially pyramidal structure and the different government and institutional setting here. It is useful to conduct research to substantiate this relationship in this country. In doing research on Malaysian pyramidal structure, this study reduces the country gap in pyramidal structure worldwide studies.

Following prior researches (Claessens et al., 2002; La Porta et al., 1999), this study focuses on the ultimate controlling shareholder rather than the immediate controlling shareholder. This is because according to Bozec and Laurin (2008), for pyramidal firms in Canada identifying an immediate controlling shareholder is insufficient for defining corporate ownership structure. Hence, when the principal shareholder of a firm is another corporate entity, the authors find the principal shareholder of that entity, and so on, until the authors find the ultimate controlling shareholder. The principal shareholder is described as the shareholder that holds at least $10 \%$ of the control rights. The authors manually collect the ultimate shareholder's control rights (CR), his cash flow rights (CFR) and the gap between his voting cash flow rights and control rights.

The following example will exemplify the process. Suppose that a family owns $40 \%$ of the shares of a publicly-traded firm A, which in turn owns $30 \%$ of the equity of firm B. In this case, the family would be identified as the ultimate controlling shareholder of firm B. The family is supposed to control indirectly $30 \%$ of the control rights in firm B (i.e., the weakest link in the chain of control rights) and about $12 \%$ of the cash flow rights (i.e., the product of $40 \%$ and $30 \%$ ). In this example, the magnitude of the divergence between cash flow rights and control rights would be 0.18 , that is, the percentage of control rights less the percentage of cash flow rights $(0.30-0.12=0.18)$.

\subsection{Research Hypothesis}

Ultimate controlling owners organize the pyramid structure in order to utilize the default options value and create opportunities for private benefits expropriation. Specifically, the authors conjecture that ultimate controlling owners expand strategies whereby they combine their cash flow rights, control rights and distance 
from affiliates with a view to minimize their sensitivity to negative shocks and maximize their sensitivity to positive shocks. Positive shocks refer to either capital or dividend gains or other forms of economic and non-economic rents. Meanwhile, negative shocks may refer to corporate value loss or dividend cut which caused by aggressive risk taking or indebtedness policies. The cash flow right over control right ratio is a proxy for the spread between ultimate control and ultimate ownership that captures the distance separating the apex from the affiliates.

Prior literature shows that affiliates with large dividend payouts, liquid stocks and high debt levels would be placed in layers that are closer to the ultimate controlling owner. However, affiliates large in size, taking aggressive risk, generate excess free cash flow and presenting means of enhancing control would be placed far down the pyramidal firm. Ultimate controlling owners generally have a preference to use minority interests' money to extract rents that secure their economic benefit. For instance, family firms at the peak of the pyramid potentially have high tendency to lobby politicians using the resources of distant affiliates, who's "profitability is relatively unimportant to them" (Morck, Stangeland, \& Yeung, 2001). Thus, the general strategy of ultimate controlling owners should be to distance themselves from the affiliates prone to negative shocks while keeping closer to them firms prone to positive shocks. Consequently, the hypothesis is that the distance between ultimate controlling owners and their affiliate's increases when the affiliates are prone to negative shocks and decreases when positive shocks dominate expectations depicted as follows:

$H_{1:}$ The distance separating the ultimate controlling owners from their affiliated firms is positively related to the presence of eventual negative shocks and negatively related to the presence of positive shocks.

$H_{1} a$ : The distance between the ultimate controlling owner and affiliates increases when affiliates are prone to negative shocks.

$H_{1} b$ : The distance between the ultimate controlling owner and affiliates decreases when affiliates are prone to positive shocks.

\section{Methodology}

\subsection{Sample and Data Collection}

Attig model (2003) is used to assess the factors determining the distance in the ownership chain between the ultimate controlling owner and the affiliated firms. To meet the objective of the study, the interaction term between the dependent variable which is cash flow right over control right ratio and explanatory variables such as risk, cash, size, TobinQ, debt ratio, dividend payout ratio, duality, financial institution as second largest shareholder and liquidity are included to capture the degree of potential private benefit expropriation. The sample covers 136 Malaysian pyramidal firms for the period of 1990 to 2010. The data are obtained from firms listed in Main Market of Bursa Malaysia Berhad (BMB) and Datastream database. In terms of extracting ownership information, data is manually collected from firms' annual reports and OSIRIS database. Balanced panel approach and pooled Generalised Least Square (GLS) methods are incorporated to estimate the regression. Previous studies are mostly based on cross-sectional data. In this research, consistent with Zheka (2006), Black, Kim, Jang, and Park (2010), Bebchuck, Cohen, and Ferrell (2009), and Bozec, Dia, and Bozec (2010), the authors use panel data in order to capture interactions of firm-specific variables and control for any unobservable firm heterogeneity in more effectively. Meanwhile, Generalised Least Square (GLS) technique may be a more appropriate statistical approach because the serial correlation of the error terms for observations from the similar firm can cause misspecification. Hence, the GLS method provides benefit of accounting for heteroscedasticity and serial correlations (firm effect and year effect), thereby generating better estimates of model parameters (Clarkson, Li, \& Richardson, 2004). All the variables studied are depicted in Table 1.

Pyramidal firms are those where at least one firm is controlled by another listed pyramidal group member. Pyramidal firms are further segregated into those at the higher tier of an ownership chain (apex) and those at the lower tier of the chain (bottom). For the purpose of this empirical analysis, only pyramidal firms with complete ownership information and other financial data are included. Pyramidal firms' data are gathered based on cash flow rights, control rights, duality function and financial institution as second largest shareholders. In this study, the authors trace actual ownership of each firm to its ultimate controlling owner which is discovered by how much control rights share (in percentage of total outstanding shares), the firm owner has. With respect to the pyramidal firms, the authors take into account the actual ownership, the control rights and the cash flow rights (CFR) to control rights (CR) ratio to capture potential dilution effects.

For the sample of pyramidal firms, the ratio of cash flow right over control right is the proxy to examine the factors that influence the length of chain in pyramidal firms towards expropriation of minority interest. Ultimate 
cash flow rights (UCFR) is incorporated in this study. It is calculated as multiplication of ownership stake used by ultimate controlling owner along the pyramidal ownership chain. Meanwhile, ultimate control right (UCR) can be measured by sum up the weakest ownership links along the pyramidal ownership chain (La Porta et al., 1999; Claessens et al., 2002). This definition depicts the risk that ultimate controlling owner possibly loses control of shareholding chain at the point when their control rights are the lowest. The authors rely on prior studies in emphasizing the following variables that may trigger the expropriation risk of minority interest as well as firm valuation. It can be conjectured that the higher the risk of expropriation, the higher the preference of the ultimate controlling owner for personal utilities maximization. As in the studies conducted by Claessens et al. (2000) and Fan and Wong (2002), Malaysian corporations reveal high levels of concentration of control.

Debt ratio is also incorporated in the regression. Debt ratio is computed as the total debt over total assets and it is used to measure firm's financial leverage. Debt can play a positive role in motivating managers to be efficient in order to meet debt repayments (Stiglitz, 1985). In contrast, debt can also exert a negative influence on firm performance because debt repayments may sometimes force ultimate controlling shareholders to forego profitable investment projects (McConnell \& Servaes, 1995). The highly levered firms are correlated with high risk. The authors also include dividend payout ratio as a factor that determines the distance in the ownership chain between the ultimate controlling owner and the affiliated firms. Dividend payout ratio represents how much earnings are distributed towards shareholders.

Size of firm is measured as the natural logarithm of total assets. Large and old firms often have more liquid trading and more diversified activities than small and young firms (Claessens et al., 2002). They also have fewer growth opportunities (Morck et al., 2002) and tend to have a numerous asset base which can be used as collateral. Large firms generally find it easier to secure external financing which are less likely to depend on bank borrowing for their financing, have lesser informational asymmetries, wider share spread and ownership profile and are more established. The authors include the log of total assets in this study to control the firm size effects on the length of chain as measured by cash flow right over control right ratio. Cash variable is also part of the regression.

The authors focus on a widely-used market-based performance measure which is Tobin's Q (see for instance, Claessens et al., 2002; Cronqvist \& Nilsson, 2003; Klein, Shapiro, \& Young, 2005). More precisely, the authors apply an approximation of Tobin's $Q(\mathrm{Q})$, which is defined as the market value of equity plus total debt divided by total assets. A high $Q$ value indicates that the capital market predicts the firm to have good growth perspectives and valuable intangibles (Cronqvist \& Nilsson, 2003). In this circumstance, Tobin's Q particularly captures the expected capitalized value of agency problems resulting from different ownership structures (Morck, Shleifer, \& Vishny, 1988).

Standard deviation of the variances of daily stock returns is a proxy for firm risk taking policy. The other variable such as duality of CEO is also incorporated in this study. Duality of CEO exists when the chairman of the board is also the CEO of the firm. In this study, duality function is highlighted where the variable takes value of one if the chairman and CEO roles are unified; otherwise it takes a value of zero. Basically, the number of firms with role duality is higher in pyramidal firms indicating that role duality is more common. Other than that, the factor such as stock liquidity is also emphasized for the purpose of this study. In this case, the authors measure stock liquidity by incorporating the yearly average value of daily percentage Bid-Ask Spread (BASP) (Attig, Gadhoum, \& Lang, 2006).

Table 1. Method of variables calculation

\begin{tabular}{lll}
\hline Variables & Description & Formula \\
\hline Risk & Standard deviation of daily stock returns & $\mathrm{SD}=\sqrt{1 / \mathrm{N} \Sigma^{\mathrm{n}} \mathrm{i}=1\left(x_{1}-\mu\right)^{2}}$ \\
Performance & Show the firm's performance & $\begin{array}{l}\text { (Market value of equity }+ \text { Total debt)/Total } \\
\text { assets }\end{array}$ \\
Debt ratio & Measure firm's financial leverage & Total debt/Total assets \\
Cash & Cash availability within the firm & Natural log of cash \\
Size & Represented by the total asset & Natural log of total asset \\
\hline
\end{tabular}




\begin{tabular}{|c|c|c|}
\hline \multirow[t]{2}{*}{ Pyramidal firm } & $\begin{array}{l}\text { A pyramidal firm is a firm affiliation to pyramid whose } \\
\text { demonstrates a top-down chain of control }(\mathrm{PAFF}=1)\end{array}$ & $\begin{array}{l}\text { Based on public listed companies in Malaysia } \\
1 \text { = Pyramidal firm }\end{array}$ \\
\hline & $\begin{array}{l}\text { Non pyramidal firm is the existence of one or more firms between } \\
\text { the one affiliate and the ultimate controlling owner which has the } \\
\text { same voting and cash flow rights compared to pyramidal } \\
\text { firm(NAFF }=0 \text { ) }\end{array}$ & $0=$ Otherwise \\
\hline Duality & $\begin{array}{l}\text { The same person serving as both the CEO and the chairman of the } \\
\text { company }\end{array}$ & $\begin{array}{l}1=\text { Act as both CEO and Chairman of Boards } \\
0=\text { Otherwise }\end{array}$ \\
\hline $\begin{array}{l}\text { Financial } \\
\text { institution } \\
\text { holding }\end{array}$ & $\begin{array}{l}\text { Elements of control from financial institution as the second largest } \\
\text { shareholders act as monitoring agent help to reduce the possibility } \\
\text { of expropriation in the pyramidal structure }\end{array}$ & $\begin{array}{l}1=\text { Status } \\
0=\text { Non status }\end{array}$ \\
\hline $\begin{array}{l}\text { Dividend } \\
\text { payout ratio }\end{array}$ & Represent how much earnings are distributed to the shareholders & Cash dividends / (Pre tax income - Income tax) \\
\hline Stock liquidity & $\begin{array}{l}\text { Yearly average of daily bid ask spread (BASP) is used to compute } \\
\text { the stock liquidity }\end{array}$ & $\mathrm{BASP}=($ Ask-bid $) /[(\text { Ask }+ \text { bid }) / 2]^{*} 100$ \\
\hline $\begin{array}{l}\text { Capital } \\
\text { expenditure }\end{array}$ & Measure for firm's investment & Total fixed assets / Total assets \\
\hline $\begin{array}{l}\text { Cash flow rights } \\
\text { (CFR) }\end{array}$ & Cash flow rights represent owner's actual ownership in a firm & $\begin{array}{l}\text { Multiplication of ownership stake along the } \\
\text { pyramidal ownership chain }\end{array}$ \\
\hline $\begin{array}{l}\text { Control rights } \\
(\mathrm{CR})\end{array}$ & $\begin{array}{l}\text { Control ratio of a shareholder is derived by dividing the share of } \\
\text { control he can exercise either directly or indirectly over a given } \\
\text { firm, by the percentage of shares he actually possesses in that firm }\end{array}$ & $\begin{array}{l}\text { The weakest ownership link along the } \\
\text { pyramidal ownership chain }\end{array}$ \\
\hline
\end{tabular}

\subsection{The Empirical Model}

For the empirical model, the authors consider only pyramidal firms; the authors examine the factors determining the distance in the chain of ownership between the ultimate controlling owner and the affiliated firms. The cash flow right over control right ratio is used and this variable is highly (negatively) correlated to the number of layers and should, ceteris paribus, capture the degree of potential private benefit of expropriation. The model explaining the variability of the ownership / control ratio is as follows:

$$
(C F R / C R)=\delta_{0}+\Sigma_{k} \delta_{k} C O V A_{k}
$$

$$
(C F R / C R)=f(\text { Risk, Size, Cash, TobinQ, DivR, DebtR, Liquidity, Duality, FIH) }
$$

In model (1), the dependent variable is the ultimate ownership over ultimate control ratio (CFR/CR). CFR is cash flow rights or ultimate ownership stakes, whereas CR is control rights or ultimate control stakes. Several control variables are also included (see model 1(a)). In general, the length of chain is expected to be positively associated with firm performance, dividend payout ratio, debt, stock liquidity and second largest shareholders. On the other hand, risk, size, free cash flow and duality are expected to give negative effect to the separation length of chain.

\section{Data Analysis}

\subsection{Descriptive Statistics}

Data description on cash flow rights and ultimate control concentration for selected Malaysian pyramidal firms is also discussed in this study. The descriptive statistics are calculated and analysis of mean, median, variance and standard deviation of all the variables including control rights (CR), cash flow right (CFR), cash flow rights leverage (CFRL) and ratio cash flow right / control right (CFR/CR) are presented in Table 2.

Pyramids create cash flow rights and control rights dispersions. The amount of increased control rights (CR) from cash flow rights (CFR) appears in the variable cash flow rights leverage (CFRL). Cash flow rights leverage (CFRL) represents the difference between cash flow rights (CFR) and control rights (CR) basically held by each ultimate controlling owner. To make the differentiation between these two rights, the authors document pyramiding structures for each firm. When control rights (CR) rise and become greater than cash flow rights (CFR) or when the ultimate controlling shareholder gain effective control via complicated ownership structures such as pyramidal ownership, ultimate controlling shareholders are more likely to expropriate in such a situation. 
For the whole sample, the mean amount of control rights is $33 \%$ (standard deviation: 9.244), with mean cash flow rights standing at $19 \%$. The deviation in these figures means that the ultimate controlling owners receive $19 \%$ of the cash flow rights generated by the firms, but control a larger proportion of the firms' voting rights (33\%). These averages are calculated over firms where at least one ultimate controlling owner possesses at least $5 \%$ of the control rights. The average value of increased control or cash flow rights leverage (CFRL) accounted for $13 \%$.

Meanwhile, the average ratio of cash flow right (CFR) to control right (CR) is small which amounted to 0.592 . To compute the corporate control concentration in pyramidal firms, both of cash flow rights and control rights are taken into consideration. Cash flow rights represent the ultimate ownership stake held by the largest ultimate controlling shareholder. Meanwhile, control rights represent the percentage of voting rights controlled by the largest ultimate controlling shareholder.

Table 2. Descriptive statistics for cash flow rights and ultimate control concentration for Malaysian pyramidal firms

\begin{tabular}{lccccc}
\hline & Mean & Max & Min & Var & Std. Dev. \\
\hline Control rights & 0.33 & 0.54 & 0.12 & 85.46 & 9.244 \\
Cash flow rights & 0.19 & 0.40 & 0.05 & 62.71 & 7.919 \\
Cash flow rights leverage & 0.13 & 0.31 & 0.04 & 38.17 & 6.178 \\
Ratio cash flow rights / Control rights & 0.592 & 0.857 & 0.156 & 0.024 & 0.154 \\
\hline
\end{tabular}

Based on a description of this data, the result for all of the variables has value of less than 1 . The disparity between cash flow rights and control rights for ultimate controlling owners is statistically significant. This disparity is even larger for ultimate controlling owners who are individuals or families which can trigger agency problems with the minority shareholders. Agency problem in Malaysia is quite a serious issue when the pyramidal firms of under developed market have concentrated shareholding. The mean of control rights reported (33\%) is higher in comparison to empirical evidences of Fan and Wong (2002) and Claessens et al. (2000). These authors reported that on average the control rights for Malaysian firms are 30.7\% and 28.3\% respectively. The justification for such results was because they economized on data collection by terminating the tracing of ultimate controlling owners once the control rights reached $50 \%$. As a consequence, their control rights statistics are lower compared to those reported in this study.

Overall, the result implies that the ultimate controlling owners tend to control the firm once their excess of voting right exceeds their cash flow rights. The existence of excess control rights has a negative implication on firm performance. The result is also similar to those of Bozec and Laurin (2008) and Attig et al. (2004) studies who both document a negative effect of excess control rights on Canadian firm performance. Their results tend to create the entrenchment problem as mentioned by Morck et al. (1988).

The result of this study, however, is consistent with the view of Shleifer and Vishny (1997) that state once "large ultimate controlling owners gain nearly full control of the firm, they prefer to generate private benefits of control that are not shared by minority shareholders". Moreover, this result is also supportive of the arguments put forward by Bebchuk et al. (2000) who report that incentives for expropriation are even stronger when control rights exceed cash flow rights. The result of this study is also supported by Claessens et al. (2000) theoretical ideas who distinguish between actual ownership and voting power. By means of a pyramidal structure, the ultimate controlling owners gain more voting rights rather than cash flow rights.

\subsection{Length of Chain Separating Ultimate Controlling Owner from Affiliates}

Table 3 presents the regression results on length of chain of ownership separating ultimate controlling owner from the affiliates. The length of chain is the dependent variable, indicated as the ultimate controlling owner's cash flow right over the control right ratio. If the ultimate controlling owner's cash flow right over control right ratio is high, it means that the deviation is low and the length of chain is short (Attig et al., 2003). In contrast, if the ratio of ultimate controlling owner's cash flow right over the control right is low, it shows that the deviation is high and the length of chain is long. This model only concentrates on the Malaysian pyramidal firms.

Table 3 investigates the length of chain factors which indicates expropriation of minority interest among Malaysian pyramidal firms. Size of firm is significant at $1 \%$ level and negatively associated to the cash flow 
right over control right ratio, thus supporting the claim that larger firms might have fewer growth opportunities (Morck et al., 2002). For the size variable, it is significantly negative related to the cash flow right over control right ratio at $1 \%$ level. Therefore, it can be conjectured that when the size is smaller, it postulates the lower the ratio of ultimate controlling owner's cash flow right over the control right.

Claessens et al. (2000) claim that most pyramidal firms in Malaysia especially the medium-size firms depict that the actual ownership and control dispersion are more pronounced giving the ultimate controlling owner an opportunity to expropriate minority shareholders' interests (Lemmon \& Lins, 2003). In this case, the results report that when the ratio of cash flow right to control right is smaller among Malaysian pyramidal firms, the tendency for the ultimate controlling owner to conduct expropriating behaviour is higher, due to longer length of ultimate controlling owner chain which affects the dilution of minority shareholders' interests. Besides that, it reveals that in Malaysian pyramidal firms, the risk and cash variables are significant at $1 \%$ significance level and negatively related to the ultimate controlling owner's cash flow right over the control right ratio which is in line with previous studies.

For duality function of CEO, this variable is significantly and negatively associated to the cash flow right over control right ratio at $1 \%$ level. The results are in accordance with previous evidence conducted by Attig et al. (2003). They also report that about $93.02 \%$ (40/43) of the pyramidal firms analyzed in their study have duality CEOs in their firms. Moreover, they also remark that the firms in their study conquer the pyramidal structure; starting from the apex right to the lower bottom of one particular pyramidal structure. Another study by Michael Sampson (2008) also provides similar evidence that dual CEOs function is inversely related to the voting over control right ratio. Dual CEOs seem to pursue self interests' purposes which are not in line with shareholders' value.

Table 3. Results of regression analysis (model: length of chain)

(Dependent variable: $\mathrm{CFR} / \mathrm{CR}$ )

\begin{tabular}{|c|c|c|c|c|}
\hline Variable & Coefficient & Std. error & t-statistic & Prob. \\
\hline Risk & -1.091041 & 0.169475 & -6.437785 & $0.0000 * * *$ \\
\hline Cash & -0.015409 & 0.006075 & -2.536344 & $0.0125 * * *$ \\
\hline Size & -0.075345 & 0.004691 & -16.06237 & $0.0000 * * *$ \\
\hline TobinQ & 0.061032 & 0.020056 & 3.043127 & $0.0029 * * *$ \\
\hline Debt ratio & 0.009896 & 0.019618 & 0.504459 & 0.6149 \\
\hline Div ratio & 0.006598 & 0.012000 & 0.549852 & 0.5835 \\
\hline Duality & -0.160513 & 0.018538 & -8.658598 & $0.0000 * * *$ \\
\hline Fin. inst & 0.152578 & 0.062780 & 2.430371 & $0.0166^{* * *}$ \\
\hline \multirow[t]{2}{*}{ Liquidity } & 0.009587 & 0.001955 & 4.904581 & $0.0000 * * *$ \\
\hline & Weighted St & & & \\
\hline R-squared & 0.267179 & \multicolumn{2}{|c|}{ Mean dependent var } & 1.314056 \\
\hline Adjusted R-squared & 0.248627 & \multicolumn{2}{|c|}{ S.D. dependent var } & 1.241702 \\
\hline S.E. of regression & 0.821441 & \multicolumn{2}{|c|}{ Sum squared resid } & 260.6595 \\
\hline Durbin-watson stat & 1.927370 & & & \\
\hline
\end{tabular}

Note. (***) indicates significance level at $1 \%$ level; $(* *)$ indicates significance at $5 \%$ level and $(*)$ indicates significance at $10 \%$ level (two-tailed).

Meanwhile, debt ratio result is positively related and statistically insignificant with the voting over control right ratio. A firm with greater debt basically is located in the layer near the top tier (apex) reflecting that they engage a vital role in establishing new subsidiaries to enhance control. This shows that the bottom of pyramidal firms are smaller, thus the positive coefficient of debt implies that they do not possess inherent traits which may permit them to borrow as much.

The other variables such as TobinQ and dividend payout ratio are also regarded as important factors which 
influence the length of chain towards expropriation of minority interest among pyramidal firms. TobinQ which is a proxy for the firm performance is significantly and positively related to the ultimate controlling owner's cash flow right over the control right ratio at $1 \%$ level. Although dividend payout ratio and the length of chain have positive relationship between each other, but the result is insignificant. Other than that, liquidity and financial institution as second largest shareholders are both significant variables at $1 \%$ significance level which also depict positive relationship with the voting over control right ratio. Hence, it can be conjectured that the liquid stock gives more information to investors who can always opt not to buy stock prone to probability of expropriation by the ultimate controlling owner. For financial institutions as second largest shareholders, it generally increases the control level in the pyramidal firms which affect the layer of equity holdings.

\section{Conclusion and Recommendations}

Apparently, the presence of magnitude divergence of cash flow rights and control rights via length of chain is recognized as creating conditions that could increase the risk of expropriation of minority shareholders interest especially among Malaysian pyramidal firms. The purpose of this study to empirically examine the length of chain factors which indicates expropriation of minority interest among pyramidal firms specifically in Malaysia. In this study, the authors apply panel data to control effectively any unobservable firm heterogeneity. This study covers a twenty-one year-period leading to more robust tests.

The present study reveals that variables such as risk, cash, size, TobinQ, duality, financial institution and liquidity are statistically significant at $1 \%$ level. Length of chain is used as dependent variable which is proxied by the ultimate controlling owner's cash flow right (CFR) over control right (CR) ratio (Attig et al., 2003). The result is consistent with the entrenchment effect that indicates the wider the divergence between cash flow rights and control rights, the more likely that ultimate controlling shareholders are keen in expropriation strategy which affect the minority shareholders' interests.

Overall, these results are in line with the view of Shleifer and Vishny (1997) that of opined that once "large ultimate controlling owners gain nearly full control of the firm, they favor to generate private benefits of control that are not shared by minority shareholders". In other words, the ultimate controlling shareholders extract amount of private benefits from firm they operate and commonly they hinder themselves not to share the cash flows of the firm with the rest of shareholders. These results are also supportive of the arguments put forward by Bebchuk et al. (2000) that argued incentives for expropriation are even stronger when control rights exceed cash flow rights. In other words, the divergence of these two rights via the length of chain in pyramidal firms aggravates the risks of minority shareholder expropriation.

Given these findings, several potential extensions for future research emerge. Firstly is to examine cross-sectionally the other dominant attributes that ascertain some pyramidal firms towards expected expropriation or rent-seeking behavior to opt for corporate mechanisms that pay out cash. In such a context, better corporate governance practices such as dividend policy can overcome the dilution of minority shareholders' interests via length of chain in pyramidal firms. Expropriation of the minority interest will be at the very minimum level and the ultimate controlling owner has a little or no room for opportunistic behaviour that may leads to devaluation of the firms. The findings of this study is useful to the regulators in deliberating policies on issues related to corporate governance, thus determining the direction of future governance policies for Malaysian corporations. This study is also beneficial to shareholders especially minority shareholders who often have been inadequately considered and protected in choosing the best suitable practices to monitor and control their directors and managers in enhancing corporate governance.

Another extension of this study is to explore whether pyramidal structure tend to seize excess cash at the top tier rather than to those at the bottom tier. Such a finding could provide support of cash being tunneled out of the pyramidal structure. Besides that, the policy makers could initiate a policy to restrict the size of the pyramidal structure (i.e.; limiting the number of firms along the pyramidal chain), which has always been the key factor contributing to the expropriation. If such policy is executed, the ultimate controlling owner would internalize more of the cost of their expropriation conducts. There should also be a minimum investment or threshold portion of cash flow right for ultimate controlling owner over the firm at the lowest chain of the pyramidal group. This threshold needs to be implemented in order to reduce the negative influence towards dilution of minority shareholders' interests.

\section{Acknowledgements}

We would like to thank the editors and the anonymous referees of the journal for constructive comments and suggestions, which have significantly helped to improve the contents of the paper. The usual caveats apply. We also would like to extend our sincere appreciation to Ministry of Higher Education (MOHE) for providing FRGS 
grant $($ vote no $=600-\mathrm{RMI} / \mathrm{SSP} / \mathrm{FRGS}$ 5/3/Fsp (80/2010) led by Prof. Dr. Norhana Salamudin of Universiti Teknologi MARA and also Research Management Institute (RMI) for facilitating the project.

\section{References}

Almeida, H., \& Wolfenzon, D. (2006). A theory of pyramidal ownership and family business groups. Journal of Finance, 61, 2637-2680. http://dx.doi.org/10.1111/j.1540-6261.2006.01001.x

Attig, N. (2007). Excess control and the risk of corporate expropriation: Canadian evidence. Canadian Journal of Administrative Sciences, 24(2), 94-106. http://dx.doi.org/10.1002/cjas.10

Attig, N., Gadhoum, Y., \& Lang, L. H. P. (2006). Effects of large shareholding on information asymmetry and stock liquidity. Journal of Banking and Finance, 30(10), 2875-2892. http://dx.doi.org/10.1016/j.jbankfin.2005.12.002

Attig, N., Fischer, K., \& Gadhoum, Y. (2003). On the determinants of pyramidal ownership: Evidence on dilution of minority interests. Halifax, Nova Scotia: Sobey School of Business, Saint Mary's University.

Attig, N., Fischer, K. P., \& Gadhoum, Y. (2004). On the determinants of pyramidal ownership: Evidence on dilution of minority interests. EFA 2004 Maastricht Meetings Paper No. 4592.

Baek, J. S., Kang, J. K., \& Park, K. S. (2004). Corporate governance and firm value: Evidence from the Korean financial crisis. Journal of Financial Economics, 71(2), 265-313. http://dx.doi.org/10.1016/S0304-405X(03)00167-3.

Bebchuck, L. A., Cohen, A., \& Ferrell, A. (2009). What matters in corporate governance? Review of Financial Studies, 22(2), 783-827. http://dx.doi.org/10.1093/rfs/hhn099

Bebchuk, L., Kraakman, R., \& Triantis, G. (2000). Stock pyramids, cross ownership, and dual class equity: The creation and agency costs of separating control from cash flow rights in concentrated corporate ownership. Edited by Randall Morck, University of Chicago Press.

Black, S. B., Kim, W., Jang, H., \& Park, K. S. (2010). How corporate governance affects firm value: Evidence on channels from Korea. Finance Working Paper No. 103/2005; KDI School of Pub Policy and Management Paper No. 08-19; Northwestern Law and Econ Research Paper No. 09-23; University of Texas Law, Law and Econ Research Paper No. 51; McCombs Research Paper Series No. 01-05. http://dx.doi.org/10.2139/ssrn.1365945

Bozec, R., Dia, M., \& Bozec, Y. (2010). Governance-performance relationship: A re-examination using technical efficiency measures. British Journal of Management, 21(3), 684-700. http://dx.doi.org/10.1111/j.1467-8551.2008.00624.x

Bozec, Y., \& Laurin, C. (2004). Concentration des droits de propriété, séparation entre participation au capital et contrôle des votes et performance opérationnelle des sociétés: Une étude Canadienne. Finance Contrôle Stratégie, 7(2), 123-164.

Bozec, Y., \& Laurin, C. (2008). Large shareholder entrenchment and performance: Empirical evidence from Canada. Journal of Business, Finance and Accounting, 35(1), 25-49. http://dx.doi.org/10.1111/j.1468-5957.2007.02066.x

Bunkanwanicha, P., \& Wiwattanakantang, Y. (2008). Allocating risk across pyramidal tiers: Evidence from Thai business group. Institute of Economic Research, Hitotsubashi University, Tokyo, Japan.

Chapelle, A. (2005). Separation between ownership and control: Where do we stand? Journal of Corporate Ownership and Control, 2(2), Winter 2005.

Cheung, Y. L., Rau, P. R., \& Stauraitis, A. (2006). Tunneling, propping and expropriation: Evidence from connected party transactions in Hong Kong. Journal of Financial Economics, 82, 343-386. http://dx.doi.org/10.1016/j.jfineco.2004.08.012

Chu, E. Y., \& Cheah, K. G. (2006). Does ownership structure matter? Evidence from Malaysian equity market. Corporate Ownership and Control, 4(1), 77-90.

Claessens, S., Djankov, S., \& Lang, L. H. P. (1999). Who control East Asian corporations? World Bank Working Paper 2054.

Claessens, S., Djankov, S., \& Lang, L. H. P. (2000). The separation of ownership and control in East Asian $\begin{array}{lllll}\text { corporations. Journal of Financial } & \text { Economics, } & 58, & 81-112 .\end{array}$ http://dx.doi.org/10.1016/S0304-405X(00)00067-2 
Claessens, S., Djankov, S., Fan, J. P. H., \& Lang, L. H. P. (2000a). Expropriation of minority shareholders in East Asia. CEI Working Paper Series No. 2000-4.

Claessens, S., Djankov, S., Fan, J. P. H., \& Lang, L. H. P. (2000b). The costs of group affiliation: Evidence from East Asia. World Bank Working Paper. http://rru.worldbank.org/research/interest/prr_stuff?working_papers?2088.pdf

Claessens, S., Djankov, S., Fan, J. P. H., \& Lang, L. H. P. (2002). Disentangling the incentive and entrenchment effects of large shareholding. The Journal of Finance, 57(6), 2741-2771. http://dx.doi.org/10.1111/1540-6261.00511

Clarkson, P., Li, Y., \& Richardson, G. (2004). The market valuation of environmental expenditures by pulp and paper companies. The Accounting Review, 79, 329-353. http://dx.doi.org/10.2308/accr.2004.79.2.329

Cronqvist, H., \& Nilsson, M. (2003). Agency costs of controlling minority shareholders. Journal of Financial and Quantitative Analysis, 38, 695-719. http://dx.doi.org/10.2307/4126740

Du, J., \& Dai, Y. (2005). Ultimate corporate ownership structures and capital structures: Evidence from East Asian economies. Corporate Governance: An International Review, 13(1), 60-71. http://dx.doi.org/10.1111/j.1467-8683.2005.00403.x

Faccio, M., \& Lang, L. H. P. (2002). The ultimate ownership of Western European corporations. Journal of Financial Economics, 65(3), 365-395. http://dx.doi.org/10.1016/S0304-405X(02)00146-0

Fan, J. P. H., \& Wong, T. J. (2002). Corporate ownership structure and the informativeness of accounting earnings in East Asia. Journal of Accounting and Economics, 33, 401-425. http://dx.doi.org/10.1016/S0165-4101(02)00047-2

Fauzias, M. N., \& Bany, A. (2005). Pyramiding effect on firm's investment decision among Malaysian distress companies. Journal of Corporate Ownership and Control, 3(1), 163-172.

Fauzias, M. N., \& Zunaidah, S. (2007). The interaction effect between ownership structure and board governance on dividends: Evidence from Malaysian listed firms. Proceedings of the Malaysian Finance Association 9th Annual Conference, Shah Alam, Selangor, Malaysia: UKM and UPM.

Friedman, E., Johnson, S., \& Mitton, T. (2003). Propping and tunneling. Journal of Comparative Economics, 31(4), 732-750. http://dx.doi.org/10.1016/j.jce.2003.08.004

Hughes, J. P. (2009). Corporate value, ultimate control and law protection for investor in Western Europe. Management Accounting Research, 20, 41-52. http://dx.doi.org/10.1016/j.mar.2008.10.004

Joh, S. W. (2003). Corporate governance and firm profitability: Evidence from Korea before the economic crisis. Journal of Financial Economics, 68, 287-322. http://dx.doi.org/10.1016/S0304-405X(03)00068-0

Khatri, Y., Leruth, L., \& Piesse, J. (2002). Corporate performance and governance in Malaysia. IMF Working Paper 02/152, Washington: International Monetary Fund.

Klein, P., Shapiro, D., \& Young, J. (2005). Corporate governance, family ownership and firm value: The Canadian evidence. Corporate Governance: An International Review, 13(6), 769-784. http://dx.doi.org/10.1111/j.1467-8683.2005.00469.x

La Porta, R., Lopez, F., \& Shleifer, A. (1999). Corporate ownership around the world. Journal of Finance, 55(1), $1-33$.

La Porta, R., Lopez, F., Shleifer, A., \& Vishny, R. W. (2000a). Investor protection and corporate governance. Journal of Financial Economics, 58(1-2), 3-27. http://dx.doi.org/10.1016/S0304-405X(00)00065-9

La Porta, R., Lopez, F., Shleifer, A., \& Vishny, R. W. (2000b). Agency problems and dividend policies around the world. The Journal of Finance, LV(1), 1-33. http://dx.doi.org/10.1111/0022-1082.00199

Lemmon, M. L., \& Lins, K. V. (2003). Ownership structure, corporate governance and firm value: Evidence from East Asian financial crisis. The Journal of Finance, LVIII(4), 1445-1468. http://dx.doi.org/10.1111/1540-6261.00573

Lins, K. V. (2003). Equity ownership and firm value in emerging markets. Journal of Financial and Quantitative Analysis, 38, 159-184. http://dx.doi.org/10.2307/4126768

McConnell, J., \& Servaes, H. (1995). Equity ownership and the two faces of debt. Journal of Financial Economics, 39, 131-57. http://dx.doi.org/10.1016/0304-405X(95)00824-X 
Michael, S. (2008). Is CEO/chair duality associated with greater likelihood of an international acquisition? Kelley School of Business, Indiana University.

Mitton, T. (2002). A cross-firm analysis of the impact of corporate governance on the East Asian financial crisis. Journal of Financial Economics, 64, 215-241. http://dx.doi.org/10.1016/S0304-405X(02)00076-4

Morck, R., Shleifer, A., \& Vishny, R. W. (1988). Management ownership and market valuation. Journal of Financial Economics, 20, 293-315. http://dx.doi.org/10.1016/0304-405X(88)90048-7

Morck, R., Stangeland, A. D., \& Yeung, B. (2001). Inherited wealth, corporate control and economic growth: The Canadian disease. Nber Working Paper No. 6814.

Morck, R., Stangeland, D., \& Yeung, B. (2002). Inherited Wealth, corporate control and economic growth: The Canadian disease in concentrated corporate ownership. In R. Morck (Ed.), National Bureau of Economic Research Conference Volume. University of Chicago Press.

Riyanto, Y. E., \& Toolsema, L. A. (2008). Tunnelling and propping: A justification for pyramidal ownership. Journal of Banking and Finance, 32, 2178-2187. http://dx.doi.org/10.1016/j.jbankfin.2007.12.044

Shleifer, A., \& Vishny, R. W. (1997). A survey of corporate governance. Journal of Finance, 52, 737-782. http://dx.doi.org/10.1111/j.1540-6261.1997.tb04820.x

Stiglitz, J. E. (1985). Credit markets and the control of capital. Journal of Money Credit Banking, 17(2), 133-152. http://dx.doi.org/10.2307/1992329

Tam, O. K., \& Tan, M. G. S. (2007). Ownership, governance and firm performance in Malaysia. Corporate Governance: An International Review, 15(2), 208-222. http://dx.doi.org/10.1111/j.1467-8683.2007.00555.x

Villalonga, B., \& Amit, R. (2006). How do family ownership, control and management affect firm value. Journal of Financial Economics, 80, 385-417. http://dx.doi.org/10.1016/j.jfineco.2004.12.005

Zheka, V. (2006). Does corporate governance causally predict firm performance? Panel data and instrumental variables evidence. CERT Discussion Paper No. DP06/05. http://dx.doi.org/10.2139/ssrn.877913

\section{Appendix A}

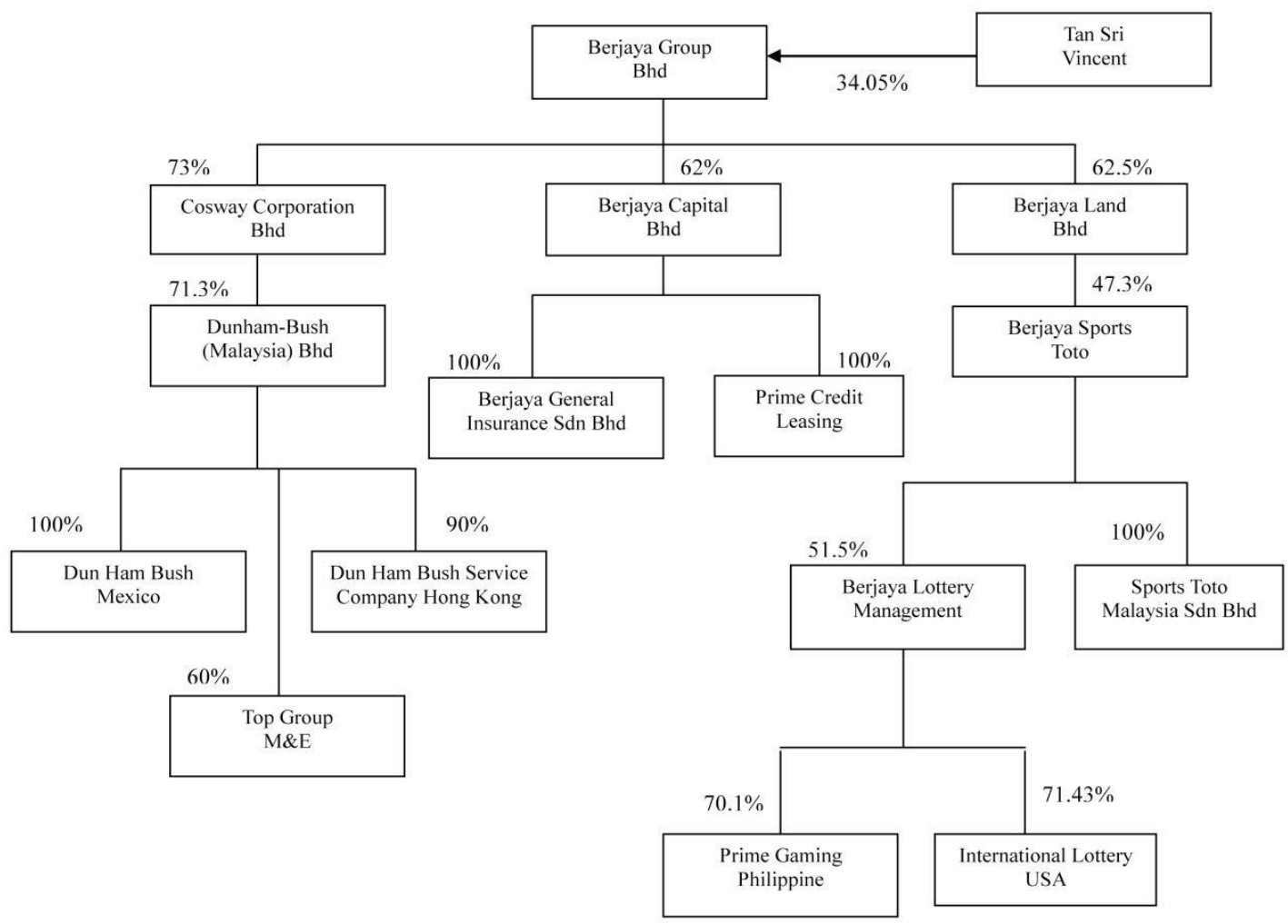

Figure A1. Group ownership structure for the Berjaya group 


\section{Appendix B}

\section{Examples of Tracking the Ultimate Controlling Owner of Pyramidal Firms}

This section presents several cases of tracking the ultimate controlling owner along the pyramidal chain and computing their cash flow right (CFR) in the firms that they controlled (refer to Appendix for Figure 1). Tan Sri Vincent Tan ultimately controls $34.05 \%$ of Berjaya Group Bhd and this controlling stake make him becomes the principal owner of Berjaya Group Bhd. Berjaya Group Bhd is the major shareholder of Cosway Corporation Bhd with controlling stakes of $73 \%$. On the other hand, Cosway Corporation Bhd is a ultimate controlling shareholder of Dunham-Bush (Malaysia) Bhd. As Dunham-Bush (Malaysia) Bhd is controlled by Cosway Corporation Bhd, this firm in return is controlled by Berjaya Group Bhd. Hence, this makes Tan Sri Vincent Tan, the ultimate controlling shareholder of Berjaya Group Bhd as the ultimate controlling owner of Dunham-Bush (Malaysia) Bhd through pyramidal firm. Based on ownership arrangements, Tan Sri vincent Tan's cash flow right (CFR) in Dunham-Bush (Malaysia) Bhd is account for $17.723 \%$ (=71.3\% x 73\% x $34.05 \%)$ while his control right (CR) is amounted to $34.05 \%$. La Porta et al. (1999) state that the control right (CR) in particular is determined in accordance with the weakest point in the chain of controlled. The cash flow right (CFR) and control right (CR) ratio which is $52.05 \%$ signifies that there is a apparent dispersion between cash flow rights and control rights in case Dunham-Bush (Malaysia) Bhd. Actually Tan Sri Vincent Tan controls a large number of firms via his holding firm, Berjaya Group Bhd. However, this study only considers those firms that are connected to the ownership chain of Dunham-Bush (Malaysia) Bhd. So, it can be conjectured that the ultimate controlling owner enhances its control of the business through length of chain of the pyramidal firms particularly in Malaysia which can affect the dilution of minority shareholders interests.

\section{Copyrights}

Copyright for this article is retained by the author(s), with first publication rights granted to the journal.

This is an open-access article distributed under the terms and conditions of the Creative Commons Attribution license (http://creativecommons.org/licenses/by/3.0/). 